\title{
Teen Excellence in Leadership Institute Handbook
}

Authored by Tonya T. Price, Associate Professor and Extension Specialist, Virginia 4-H; Sarah A. Bush, Doctoral Candidate, Agricultural, Leadership, and Community Education, Virginia Tech; Benjamin B. Grove, MBA, Assistant Director, Global Programs, College of Agriculture and Life Sciences, Virginia Tech, and Virginia Cooperative Extension;

Jeremy C. Johnson, M.Ed., State 4-H Program Leader, Virginia 4- $\mathrm{H}$; and

Megan M. Seibel, Ph.D., Extension Specialist, Virginia Cooperative Extension, and VALOR Director

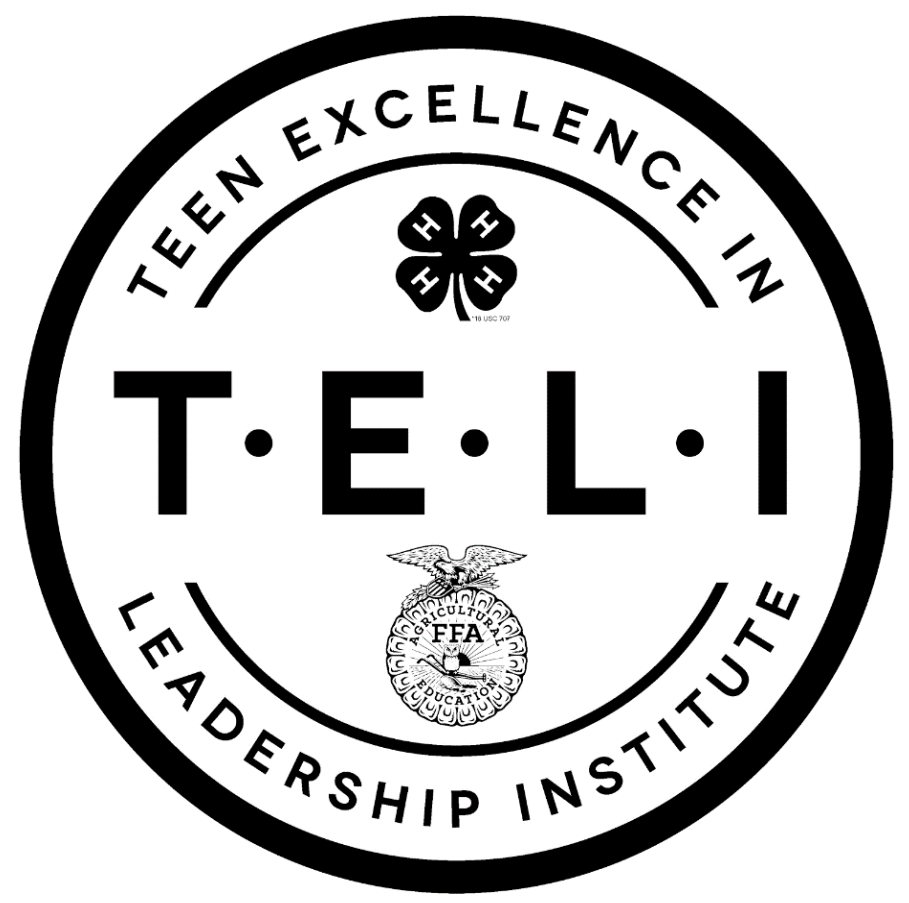

www.ext.vt.edu 


\section{CONTENTS}

Background 3

TELI Conceptual Model 5

Understanding of Self 5

Developing a Network $\quad 6$

Community Problem-Solving 6

$\begin{array}{ll}\text { Advocacy } & 7\end{array}$

$\begin{array}{ll}\text { Planning Process } & 8\end{array}$

$\begin{array}{ll}\text { Situation Analysis } & 8\end{array}$

$\begin{array}{ll}\text { Working With Stakeholders } & 8\end{array}$

Educational Program Design and Implementation 9

Program Evaluation and Reporting 11

Application Process $\quad 12$

$\begin{array}{ll}\text { Goals } & 13\end{array}$

Sample Schedule Outline 14

Note: Exact schedules and activities vary by cohort and are adjusted based on feedback.

The examples below are from Cohort 2, Fall 2015-Spring 2016.

Weekend $1 \quad 14$

$\begin{array}{ll}\text { Virtual Check-In } 1 & 15\end{array}$

$\begin{array}{ll}\text { Virtual Check-In } 2 & 15\end{array}$

Weekend $2 \quad 16$

$\begin{array}{ll}\text { Outline of Activities - By Goals } & 17\end{array}$

Sample Instruction (Cohort 2) - By Goals 19

Goal $1+19$

Goal $2+22$

Goal $3 \quad 25$

Goal $4 \quad 29$

Evaluation and Program Improvement $\quad 30$

$\begin{array}{ll}\text { References } & 31\end{array}$

$\begin{array}{ll}\text { Appendices } & 32\end{array}$ 
In 2013, the Virginia Cooperative Extension's Leadership, Volunteerism, and Civic Engagement program team identified the need for (1) prepared leaders, (2) more representative civic engagement, and (3) increased capacity to foster volunteerism. Simultaneously, conversations began regarding a need to further develop leadership training and experiences for 4-H and FFA teens that would help them become active and engaged community members. A faculty team was formed to develop a statewide youth leadership program in response to these needs. Throughout 2013, this team met to design an integrated and dynamic youth leadership program to be roughly modeled after the adult agricultural leadership development program in Virginia, Virginia Agricultural Leaders Obtaining Results (VALOR).

In this process, the team identified 4-H and FFA as two youth development organizations with agriculture education and leadership development as priorities. Leaders of these two organizations identified the need to better integrate motivated youth from both organizations for collective capacity building. Therefore, the team selected 4-H and FFA members as participants for the new youth leadership program and developed novel programming to provide high quality experiences that differed from the opportunities already available in the respective organizations.

The planning team designed a program that was theoretically informed by Chickering's (1993) Theory of Identity — commonly utilized by FFA — and the 4-H Citizenship Framework. The team intertwined Chickering's seven vectors, listed below, along with the 4-H Citizenship Framework's key focus areas of civic engagement, service, civic education, and personal development (4-H 2011).

1. Developing competence.

2. Managing emotions.

3. Moving through autonomy toward interdependence.

4. Developing mature interpersonal relationships.

5. Establishing identity.

6. Developing purpose.

7. Developing integrity.

The result of these intertwined theories was the Teen Excellence in Leadership Institute. The TELI program goals are (1) to understand self and develop a personalized action plan for engaged leadership, (2) to network with other teens interested in learning about the issues facing youth and communities, (3) to design a team project to address community leadership needs in Virginia, and (4) to learn more about advocacy and outreach that will improve the lives of others.

The TELI program includes two face-to-face weekend retreats and two virtual sessions delivered over three months. The program was designed for a maximum of 25 emerging leaders in the 10th and 11th grades who seek to practice and advance their leadership skills. 
Topics covered included: strengths-based leadership, problem-solving style, group facilitation skills, adult-youth partnerships, team building, project collaboration, peer feedback and evaluation, effective communication, leadership principles, etiquette, civic change initiatives, and critical reflection. The virtual sessions provide an opportunity for team project development and updates, which are recorded and archived. Additionally, participants engage in a team project to design a response to a community issue in Virginia. Youth-adult partnerships are incorporated through assigned team project mentors who serve as a source of knowledge and feedback. Since the inaugural cohort in 2014, the TELI program has reached over 70 teens. Evaluation data suggest teens completing the TELI program experience gains in their ability to set goals, solve problems, and plan community change initiatives. 
The TELI program's four-component model was informed by Chickering's (1993) Theory of Identity Development and the 4-H Citizenship Framework, as shown in the TELI Model (fig.1). Chickering's Theory of Identity Development, which is commonly utilized within FFA, provided guidance for the development of the seven vectors: developing competence, managing emotions, moving through autonomy toward interdependence, developing mature interpersonal relationships, establishing identity, developing purpose, and developing integrity. In addition, this program uses the 4-H Citizenship Framework by incorporating the key focus areas of civic engagement, service, civic education, and personal development (4-H 2011). The incorporation of these frameworks provided a solid foundation for youth leadership development and resulted in the development of a fourcomponent model. The model components include understanding of self, advocacy, developing a network, and community problem-solving.

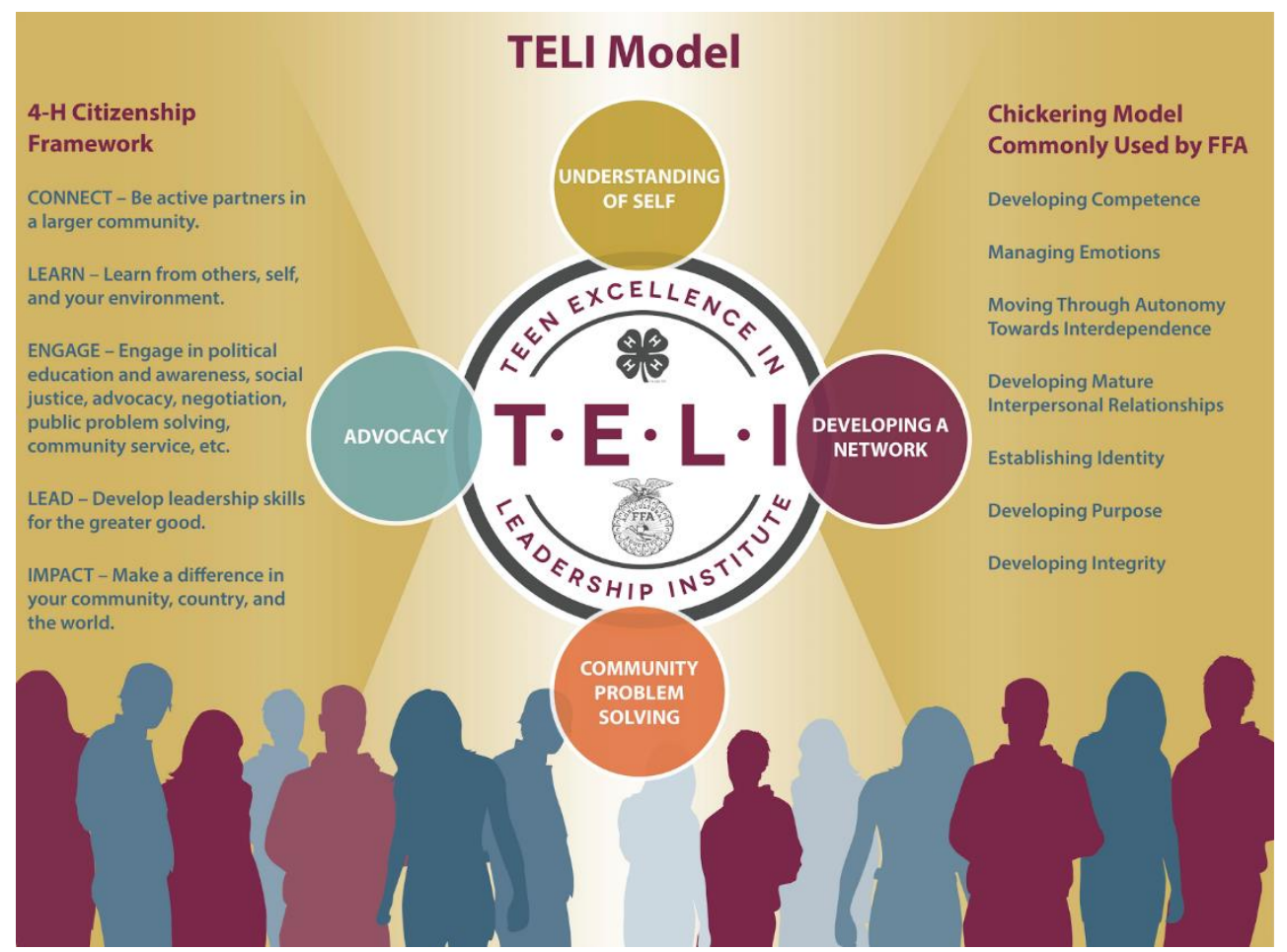

Figure 1. Graphic representation of the TELI Model. (Figure courtesy of the Office of

Communications and Marketing, College of Agriculture and Life Sciences, Virginia Tech, 2015.)

\section{Understanding of Self}

In an effort to develop self-awareness, the TELI Model involves developing teen leaders' understanding of self. It is essential for leaders to understand themselves, their leadership styles, and how they interact with others. Shamir and Eilam (2005) proposed that authentic leaders use a meaning system to develop their sense of self, which is reinforced through life stories and self-reflection. Through this process, teens develop self-concept, clarity of values and beliefs, goals focused on self-concept, and heightened self-expressive behavior. 
Developing their sense of self is the first step for teen participants in learning how to be effective community leaders.

The TELI Model uses both learn and lead constructs from the 4-H Citizenship Framework (4-H 2011) in addition to the development of intellectual competence, emotional awareness, self-regulation, self-sufficiency, and identify formation (Chickering 1993). Within the model, activities are incorporated to include self-discovery processes, selfchosen goals, and opportunities for autonomy. TELI uses self-assessments, strengths training, the development of a personalized action plan, and self- and group-reflection opportunities to promote the development of an understanding of self.

\section{Developing a Network}

The second component of the TELI Model is to provide an opportunity for participants to develop a network and the skills necessary for future networking. Within the TELI program, teens build a peer community of practice. "Communities of practice are groups of people who share a concern or a passion for something they do and learn how to do it better as they interact regularly" (Wenger 2011,1). Teens in the TELI program share a common interest in becoming change agents to address community issues.

This component includes connect, learn, and engage from the 4-H Citizenship Framework (4-H 2011) and aims to develop interpersonal competence, emotional independence, and mature relationships (Chickering1993). Network development activities are composed of social time, team-building exercises, reflection, self-marketing, etiquette training, social media training, and other networking activities. The TELI leadership team and mentors build trust over the first weekend to provide a safe space for participants to be vulnerable during shared reflection.

\section{Community Problem-Solving}

Community problem-solving is integrated as component within the TELI program, which is incorporated through community issue identification and a team project. The team project requires teens to design a response to a community issue within Virginia. Communities are faced with a variety of "wicked problems" that require teams of diverse change agents to identify the key elements of the issue and design viable solutions. Wicked problems are complex in nature and are bound within their environment. Any solution will have both positive and adverse impacts on the environment (Grint 2005). The TELI program provides an opportunity for participants to develop problem-solving and collaboration skills to increase their capacity to develop solutions for wicked problems in their local communities.

By designing a project to address a community need, teens begin to develop competence for functioning as a team as well as instrumental independence for problem-solving (Chickering 1993). Connect, engage, and impact are core concepts within the 4-H Citizenship Framework that are encompassed in the community problem-solving 
component (4-H 2011). Teens participating in the TELI program are challenged to discover their role in community problem-solving to drive change locally and globally. The TELI Model aids to promote leadership and integrity development by investing time in exploration of core values and beliefs during the decision-making process. Team-building exercises, group facilitation training, and mentored team-based projects are incorporated as activities for community problem-solving.

\section{Advocacy}

The fourth component of the TELI Model is advocacy. Through advocacy awareness and allowing engagement in outreach opportunities, teen leaders increase civic-mindedness and are more likely to engage within their local communities (Villarruel et al. 2003). Working in small groups, TELI participants identify a community-based problem, collect reliable information on their problem, and engage within their communities to garner support, information, and resources.

To promote advocacy and future outreach efforts, the program incorporates legislative advocacy, leadership in practice, and community service activities. From the 4-H Citizenship Framework, engage, lead, and impact are incorporated within advocacy development (4-H 2011). By developing an understanding of how one can make a difference within their community, integrity can be developed through humanizing values (Chickering 1993). At the core of this component is the growth of change agents with voices within their communities. 
The TELI planning team used the VCE Program Design and Implementation Module (Lambur 2019) and the VCE Program Planning Process Model (fig. 2) for guidance.

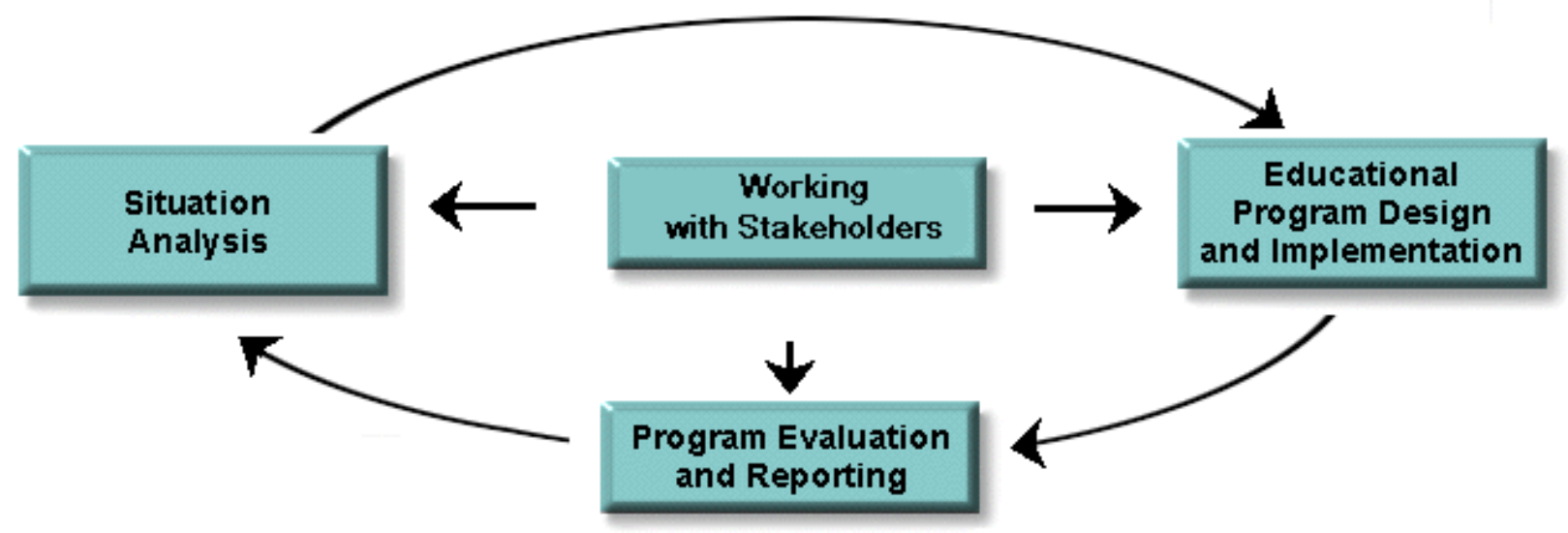

Figure 2. VCE’s Program Planning Process Model.

\section{Situation Analysis}

The Leadership, Volunteerism, and Civic Engagement program team was formed to respond to identified needs in the VCE (2010) strategic plan and is complemented by the TELI leadership team's efforts to develop youth leaders prepared to be self-directed, contributing members of society. The resulting TELI program was developed with the following focus, goal, and objective in mind.

Focus Area III. Creating a Positive Future Through 4-H Youth Development

Goal 1. Improve competencies of Virginia youth in the following life skills: knowledge, reasoning, creativity, communication, networking, citizenship, and health.

Objective 1.2. Increase engagement of all youth within the community, utilizing decision-making and problem-solving skills.

\section{Working with Stakeholders}

The following identified stakeholders have a passion for leadership and positive youth development. Additionally, they are aware of and can provide insight into the leadership traits needed for success in adulthood.

- VALOR.

- Virginia 4-H.

- Virginia FFA. 
- Virginia Farm Bureau.

- Virginia AgVocates.

- Department of Agricultural, Leadership, and Community Education, Virginia Tech.

- 4-H Center staff.

- VCE agents.

- FFA advisors/agriculture teachers.

- Virginia Tech faculty.

- Virginia Tech students.

- State 4-H Cabinet and Ambassadors.

- Virginia FFA state officers.

- Virginia 4-H Foundation.

- Virginia Cooperative Extension Leadership Council.

- VCE administration.

\section{Educational Program Design and Implementation}

The following six basic steps outline the educational program design and implementation for the TELI program, based upon the VCE Program Design and Implementation Module (Lambur, 2019).

\section{Step 1. Develop program goals and objectives.}

Goals of TELI include:

1. Understand self and develop a personalized action plan for engaged leadership.

2. Network with other teens interested in learning about issues facing youth and communities.

3. Design a team project to address community leadership needs in Virginia.

4. Learn more about advocacy and outreach that will improve the lives of others.

\section{Step 2. Understand the dynamics of learners.}

The TELI program incorporates a variety of activities to accommodate the various learning styles of participants. Training is delivered to teen participants through face-to-face meetings, virtual check-ins, and mentoring sessions.

The following learner styles are accommodated through the listed activities:

- Visual - PowerPoint, videos, mind mapping (facilitation).

- Auditory - Music, active listening, recording of virtual sessions.

- Verbal - Lecture, guest presenters, reporting (small and large group).

- Physical - Ropes course, experiential exercises.

- Intrapersonal - Self-assessment and reflection (CliftonStrengths, Kirton's Adaption-Innovation Inventory [KAI], goal setting).

- Interpersonal - Group work and presentations, social time.

- Logical - CliftonStrengths, KAI, problem-solving, group facilitation. 


\section{Step 3. Design the Extension educational program.}

The TELI program links the 4-H Citizenship Framework (2011) and the Chickering Model (1993) through the four-component TELI Model. This model (fig. 1) includes understanding of self, advocacy, developing a network, and community problem-solving. Curriculum was developed by breaking learning content into manageable segments and sequencing activities appropriately.

\section{Step 4. Develop a marketing plan and strategy.}

The following marketing materials and processes were developed for recruitment and program promotion efforts:

- A flyer, application, and nomination form.

- Advertising via multiple channels, including word-of-mouth, Listservs, FFA State Convention, 4-H Congress announcements, and past participants.

- A nomination and application process.

- A rubric for an objective application review and selection process.

\section{Step 5. Develop a program plan and strategy.}

To develop a program plan and strategy, the TELI leadership team identified roles and responsibilities, developed a financial plan, and created a succession plan.

Roles and responsibilities: The TELI team designated roles and responsibilities for the core leadership team, recruited outside experts for content delivery and a professional panel for project evaluation, and obtained administrative support.

Development of financial plan: The TELI team created a funding model that combined private support from endowed funds and annual donors, investment by the 4-H and FFA programs in Virginia, and participant registration fees.

Succession plan: The succession plan was discussed by identifying how roles would be developed and transitioned over time to expand the committee and replace members as needed.

\section{Step 6. Implement the Extension educational program plan.}

The TELI leadership team took the following actions to implement the program:

- Host sites and dates were selected based on the location, lodging facilities, environment (indoor/outdoor space), and access to technology.

- A recruitment flyer, recruitment emails, nomination forms, and application forms were developed and delivered to FFA advisors and 4-H Extension agents in Virginia.

- Nominated applicants were screened and selected for program participation.

- Schedules for meetings and sessions were developed and guest presenters were secured.

- Program planning incorporated a variety of educational delivery strategies. 
- TELI leadership team members created a system of checks and balances for accountability of team members.

Program Evaluation and Reporting

The TELI leadership team developed an evaluation plan, which utilized a retrospective prepost design of 4-H's 16 citizenship common measures. Personal goal sheets, action planning worksheets, and project reports were also utilized to evaluate the program. Results from the program evaluation and program improvements are included on page 30. 
Advertising for TELI applicants is conducted through the distribution of a recruitment flyer (Appendix A) to 4-H Extension agents, FFA advisors, past participants, participants in FFA State Convention, and participants at 4-H State Congress. The TELI participant selection process is competitive and requires a nomination (Appendix B) from each applicant's FFA advisor or 4-H Extension agent as well as a detailed application (Appendix C) that is completed by the teen. TELI leadership team members independently review the applications and nominations using a rubric. Applicants are awarded up to three points for their answers to each of the eight questions on the application (24 points), for their grammar and spelling ( 3 points), and for their nomination form ( 3 points), for a maximum of 30 points. Responses are rated as $0=$ no response, $1=$ minimal response, $2=$ average response, $3=$ outstanding response. The TELI leadership team members then meet to discuss participants' scores and select participants for the program. 


\section{The TELI program seeks to accomplish the following goals:}

1. To understand self and develop a personalized action plan for engaged leadership.

2. To network with other teens interested in learning about the issues facing youth and communities.

3. To design a team project to address community leadership needs in Virginia.

4. To learn more about the advocacy and outreach that will improve the lives of others.

Estimated time: 48 hours of instruction, as part of 85 hours of contact time over eight days (including two Friday-Sunday weekend trainings and two 2-hour virtual check-ins). Note: To complete their team projects, participants will work with their mentors for additional mentoring sessions that will vary in length of time. 
SAMPLE SCHEDULE OUTLINE

Note: Exact schedules and activities vary by cohort and are adjusted based on feedback.

The examples below are from Cohort 2, Fall 2015-Spring 2016.

\begin{tabular}{|c|c|c|}
\hline When? & What? & How long? \\
\hline Day 1: 7:00-7:45 pm & Welcome, Intros, Get-Acquainted Activities & 45 minutes \\
\hline Day 1: 7:45-7:55 pm & Why are you here? Goals and Objectives & 10 minutes \\
\hline Day 1: 7:55-8:15 pm & $\begin{array}{l}\text { Inspirational Engagement Kick-Off (Guest } \\
\text { Speaker) }\end{array}$ & 20 minutes \\
\hline Day 1: 8:15-10:30 pm & Strengths-Based Leadership (CliftonStrengths) & $\begin{array}{l}2 \text { hours and } \\
15 \text { minutes }\end{array}$ \\
\hline Day 1: 10:30-11:30 pm & Reflection and Social Time & 1 hour \\
\hline Day 2: 8:00-8:30 am & Breakfast & 30 minutes \\
\hline Day 2: 8:30-10:30 am & Creating Your Story & 2 hours \\
\hline Day 2: 10:30 am-12:00 pm & Problem-Solving Style & $\begin{array}{l}1 \text { hour and } \\
30 \text { minutes }\end{array}$ \\
\hline Day 2: 12:00-12:30 pm & Lunch & 30 minutes \\
\hline Day 2: 12:30-3:00 pm & Ropes Course - Team Leadership Building & $\begin{array}{l}2 \text { hours and } \\
30 \text { minutes }\end{array}$ \\
\hline Day 2: 3:00-3:30 pm & Break & 30 minutes \\
\hline Day 2: 3:30-5:30 pm & Generations and Social Media & $\begin{array}{l}2 \text { hours and } \\
30 \text { minutes }\end{array}$ \\
\hline Day 2: 5:30-6:00 pm & Break & 30 minutes \\
\hline Day 2: 6:00-7:00 pm & Dinner & 1 hour \\
\hline Day 2: 7:00-10:00 pm & Group Facilitation Training & 3 hours \\
\hline Day 2: 10:00-11:00 pm & Reflection and Social Time & 1 hour \\
\hline
\end{tabular}




\begin{tabular}{|l|l|l|}
\hline & & \\
\hline Day 3: 8:00-9:00 am & Breakfast/Pack Up Rooms & 1 hour \\
\hline Day 3: 9:00-11:15 am & Developing Your Plan of Work & $\begin{array}{l}2 \text { hours and } \\
15 \text { minutes }\end{array}$ \\
\hline Day 3: 11:15 am-12:00 pm & Debrief, Recap, and Moving Forward & 45 minutes \\
\hline
\end{tabular}

Virtual Check-In 1

\begin{tabular}{|l|l|l|}
\hline When? & \multicolumn{1}{|c|}{ What? } & How long? \\
\hline 7:00-7:20 pm & Weekend 1 Recap & 20 minutes \\
\hline 7:20-7:45 pm & Group Project Overview & 25 minutes \\
\hline 7:45-8:30 pm & Giving and Receiving Constructive Feedback & 45 minutes \\
\hline 8:30-9:00 pm & Overflow Time and Questions & 30 minutes \\
\hline
\end{tabular}

Virtual Check-In 2

\begin{tabular}{|l|l|l|}
\hline When? & \multicolumn{1}{|c|}{ What? } & How long? \\
\hline 7:00-7:30 pm & Legislative Advocacy & 30 minutes \\
\hline $7: 30-7: 45 \mathrm{pm}$ & Team 1 Presentation & 15 minutes \\
\hline 7:45-8:00 pm & Team 2 Presentation & 15 minutes \\
\hline 8:00-8:15 pm & Team 3 Presentation & 15 minutes \\
\hline $8: 15-8: 30 \mathrm{pm}$ & Team 4 Presentation & 15 minutes \\
\hline $8: 30-9: 00 \mathrm{pm}$ & Overflow Time and Questions & 30 minutes \\
\hline
\end{tabular}




\section{Weekend 2}

\begin{tabular}{|l|l|l|}
\hline When? & \multicolumn{1}{|c|}{ What? } & How long? \\
\hline Day 1: 7:00-8:00 pm & Welcome, Session Overview, Icebreakers & 1 hour \\
\hline Day 1: 8:00-9:00 pm & TEDx Talk on Utilizing Your Strengths & 1 hour \\
\hline Day 1: 9:00-10:45 pm & Group Project Planning & 1.75 hours \\
\hline & & \\
\hline Day 2: 8:00-8:45 am & Breakfast & 45 minutes \\
\hline Day 2: 8:45-9:30 am & Mentored Group Presentation Preparation & 45 minutes \\
\hline Day 2: 9:30-11:30 am & Formal Group Presentations with Guest Panel & 2 hours \\
\hline Day 2: 11:30 am-12:00 pm & Networking with Guest Panel & 30 minutes \\
\hline Day 2: 12:00-12:45 pm & Lunch & 45 minutes \\
\hline Day 2: 1:00-3:30 pm & Service Project & 2 hours and \\
\hline Day 2: 3:30-5:30 pm & Crucial Conversations & 2 hours \\
\hline Day 2: 5:30-6:00 pm & Break & 30 minutes \\
\hline Day 2: 6:00-7:30 pm & Etiquette Dinner & $\begin{array}{l}1 \text { hour and } \\
30 \text { minutes }\end{array}$ \\
\hline Day 2: 8:00-9:00 pm & TELI Marketing Activity & 1 hour \\
\hline Day 2: 9:00-11:00 pm & Movie Night & 2 hours \\
\hline Day 3: 8:00-8:45 am & Breakfast/Pack Up Rooms & 45 minutes \\
\hline Day 3: 9:00-9:15 am & Program Debrief - Connection Web & 15 minutes \\
\hline Day 3: 9:15-10:00 am & Focus Groups & 45 minutes \\
\hline Day 3: 10:00-10:45 am & Development of Personalized Action Plan & 45 minutes \\
\hline Day 3: 10:45-11:30 am & Evaluation with Common Measures \\
\hline
\end{tabular}




\begin{tabular}{|c|c|c|c|}
\hline Inputs & Model & Goal & Outputs \\
\hline $\begin{array}{l}\text { Strengths-based leadership } \\
\text { (CliftonStrengths) }\end{array}$ & Understanding of self & $\begin{array}{l}\text { Understand self and } \\
\text { develop a personalized } \\
\text { action plan for engaged } \\
\text { leadership. }\end{array}$ & $\begin{array}{l}\text { - I set goals for myself. } \\
\text { - I have a plan for reaching my } \\
\text { goals. } \\
\text { - I have talents I can offer others. }\end{array}$ \\
\hline $\begin{array}{l}\text { Get-acquainted activities } \\
\text { - Social time } \\
\text { Pouth-adult Partnership } \\
\text { - Reflection/social time } \\
\text { - Etiquette dinner }\end{array}$ & Developing a network & $\begin{array}{l}\text { Network with other } \\
\text { teens interested in } \\
\text { learning about issues } \\
\text { facing youth and } \\
\text { communities. }\end{array}$ & $\begin{array}{l}\text { - I know community leaders who } \\
\text { support me. } \\
\text { - I can contact someone I have } \\
\text { never met before to get help with } \\
\text { a problem. } \\
\text { - I have the confidence to speak in } \\
\text { front of groups. }\end{array}$ \\
\hline $\begin{array}{l}\text { Ropes course team } \\
\text { leadership building } \\
\text { Group facilitation training } \\
\text { (identifying community } \\
\text { issues activity) } \\
\text { Developing your plan of } \\
\text { work } \\
\text { Group project }\end{array}$ & $\begin{array}{l}\text { Community problem- } \\
\text { solving }\end{array}$ & $\begin{array}{l}\text { Design a team project to } \\
\text { address community- } \\
\text { leadership needs in } \\
\text { Virginia. }\end{array}$ & $\begin{array}{l}\text { - I am willing to consider the ideas } \\
\text { of others even if they are different } \\
\text { from mine. } \\
\text { - I like to work with others to solve } \\
\text { problems. } \\
\text { I I am able to lead a project that } \\
\text { will make a difference in my } \\
\text { community. } \\
\text { I help make sure everyone gets an } \\
\text { opportunity to say what they } \\
\text { think. } \\
\text { - I treat everyone fairly and equally } \\
\text { when I am in charge of a group. } \\
\text { - I am able to lead a group in } \\
\text { making a decision. }\end{array}$ \\
\hline $\begin{array}{l}\text { Communications and media } \\
\text { relations } \\
\text { Long-distance collaboration } \\
\text { Leadership in practice }\end{array}$ & Advocacy & $\begin{array}{l}\text { Learn more about } \\
\text { advocacy and outreach } \\
\text { that will improve the } \\
\text { lives of others. }\end{array}$ & $\begin{array}{l}\text { - I pay attention to new events that } \\
\text { affect my community. } \\
\text { - When I hear about an issue, I try } \\
\text { to figure out if they are just telling } \\
\text { one side of the story. } \\
\text { - I plan to work on projects to } \\
\text { better my community. } \\
\text { - After high school, I will continue } \\
\text { to work to better my community. }\end{array}$ \\
\hline
\end{tabular}




\begin{tabular}{|c|c|c|c|}
\hline \multicolumn{4}{|c|}{ TELI Process - Cohort 2} \\
\hline Inputs & Model & Goal & Outputs \\
\hline $\begin{array}{l}\text { Strengths-based leadership } \\
\text { (CliftonStrengths) } \\
\text { Problem-solving style } \\
\text { (KAI) } \\
\text { Creating your story } \\
\text { Strengths video } \\
\text { Developing your personal } \\
\text { action plan }\end{array}$ & Understanding of self & $\begin{array}{l}\text { Understand self and } \\
\text { develop a personalized } \\
\text { action plan for engaged } \\
\text { leadership. }\end{array}$ & $\begin{array}{l}\text { - I set goals for myself. } \\
\text { - I have a plan for reaching my } \\
\text { goals. } \\
\text { - I have talents I can offer others. }\end{array}$ \\
\hline $\begin{array}{l}\text { - Get-acquainted activities } \\
\text { Social time } \\
\text { media } \\
\text { - Reflection and social time } \\
\text { petworking with guest } \\
\text { panel } \\
\text { Etiquette dinner } \\
\text { TELI marketing }\end{array}$ & Developing a network & $\begin{array}{l}\text { Network with other } \\
\text { teens interested in } \\
\text { learning about issues } \\
\text { facing youth and } \\
\text { communities. }\end{array}$ & $\begin{array}{l}\text { - I know community leaders who } \\
\text { support me. } \\
\text { - I can contact someone I have never } \\
\text { met before to get help with a } \\
\text { problem. } \\
\text { - I have the confidence to speak in } \\
\text { front of groups. }\end{array}$ \\
\hline $\begin{array}{l}\text { Ropes course team } \\
\text { leadership building } \\
\text { Group facilitation training } \\
\text { (identifying community } \\
\text { issues activity) } \\
\text { Developing your plan of } \\
\text { work } \\
\text { Group project } \\
\text { Giving and receiving } \\
\text { feedback } \\
\text { Crucial conversations }\end{array}$ & $\begin{array}{l}\text { Community problem- } \\
\text { solving }\end{array}$ & $\begin{array}{l}\text { Design a team project to } \\
\text { address community- } \\
\text { leadership needs in } \\
\text { Virginia. }\end{array}$ & $\begin{array}{l}\text { - I am willing to consider the ideas } \\
\text { of others even if they are different } \\
\text { from mine. } \\
\text { - I like to work with others to solve } \\
\text { problems. } \\
\text { - I am able to lead a project that will } \\
\text { make a difference in my } \\
\text { community. } \\
\text { - I help make sure everyone gets an } \\
\text { opportunity to say what they think. } \\
\text { - I treat everyone fairly and equally } \\
\text { when I am in charge of a group. } \\
\text { - I am able to lead a group in } \\
\text { making a decision. }\end{array}$ \\
\hline $\begin{array}{l}\text { Legislative advocacy } \\
\text { - Service project }\end{array}$ & Advocacy & $\begin{array}{l}\text { Learn more about } \\
\text { advocacy and outreach } \\
\text { that will improve the } \\
\text { lives of others. }\end{array}$ & $\begin{array}{l}\text { - I pay attention to new events that } \\
\text { affect my community. } \\
\text { - When I hear about an issue, I try to } \\
\text { figure out if they are just telling } \\
\text { one side of the story. } \\
\text { - I plan to work on projects to better } \\
\text { my community. } \\
\text { - After high school, I will continue } \\
\text { to work to better my community. }\end{array}$ \\
\hline
\end{tabular}




\section{SAMPLE INSTRUCTION (COHORT 2) - BY GOALS}

The following goals and activities reflect those used in Cohort 2. Goals remain the same for each cohort, but supporting activities may vary by cohort to leverage content-area expertise.

\section{Goal 1}

To understand self and develop a personalized action plan for engaged leadership.

\section{Key Concepts:}

1. Strengths-based leadership training provides participants with an understanding of their strengths rather than focusing on personal weaknesses.

2. Problem-solving style training provides participants with a better understanding of the way they interact with others during problem-solving.

3. Participants will learn to communicate their passions in short and meaningful actions and stories.

4. Participants will develop a personal action plan for leadership.

\section{Pre-Work:}

- Participants complete CliftonStrengths assessment.

- Participants complete Kirton's Adaption-Innovation Inventory.

\begin{tabular}{|c|c|c|}
\hline Who? & What? & How Long? \\
\hline $\begin{array}{l}\text { Trained } \\
\text { Strengths } \\
\text { practitioner } \\
\text { leads the } \\
\text { conversation }\end{array}$ & $\begin{array}{l}\text { Strengths-Based Leadership } \\
\text { A. The participants will receive the results from the } \\
\text { CliftonStrengths assessment and participate in a session } \\
\text { led by a trained Strengths practitioner. This session will } \\
\text { include self-reflection, the development of understanding } \\
\text { how to implement strengths, and an appreciation for the } \\
\text { different strengths of others. }\end{array}$ & $\begin{array}{l}2 \text { hours and } \\
15 \text { minutes }\end{array}$ \\
\hline $\begin{array}{l}\text { Certified } \\
\text { Kirton's } \\
\text { Adaption- } \\
\text { Innovation } \\
\text { (KAI) } \\
\text { practitioner } \\
\text { leads the } \\
\text { conversation }\end{array}$ & $\begin{array}{l}\text { Problem-Solving Style } \\
\text { A. The participants will be provided with their KAI scores } \\
\text { and participate in a session led by a certified KAI } \\
\text { practitioner. This session will include detailed information } \\
\text { on: } \\
\text { - Roles as change agents. } \\
\text { - The cognitive schema. } \\
\text { - Traits and characteristics of problem-solving styles. } \\
\text { - Preference for defining problems. } \\
\text { - Preference for generating solutions. } \\
\text { - Preference for rules and groups. } \\
\text { - How participants relate to the world and to each } \\
\text { other. }\end{array}$ & $\begin{array}{l}1 \text { hour and } \\
30 \text { minutes }\end{array}$ \\
\hline
\end{tabular}




\begin{tabular}{|c|c|c|}
\hline $\begin{array}{l}\text { Facilitator leads } \\
\text { discussion and } \\
\text { activity }\end{array}$ & 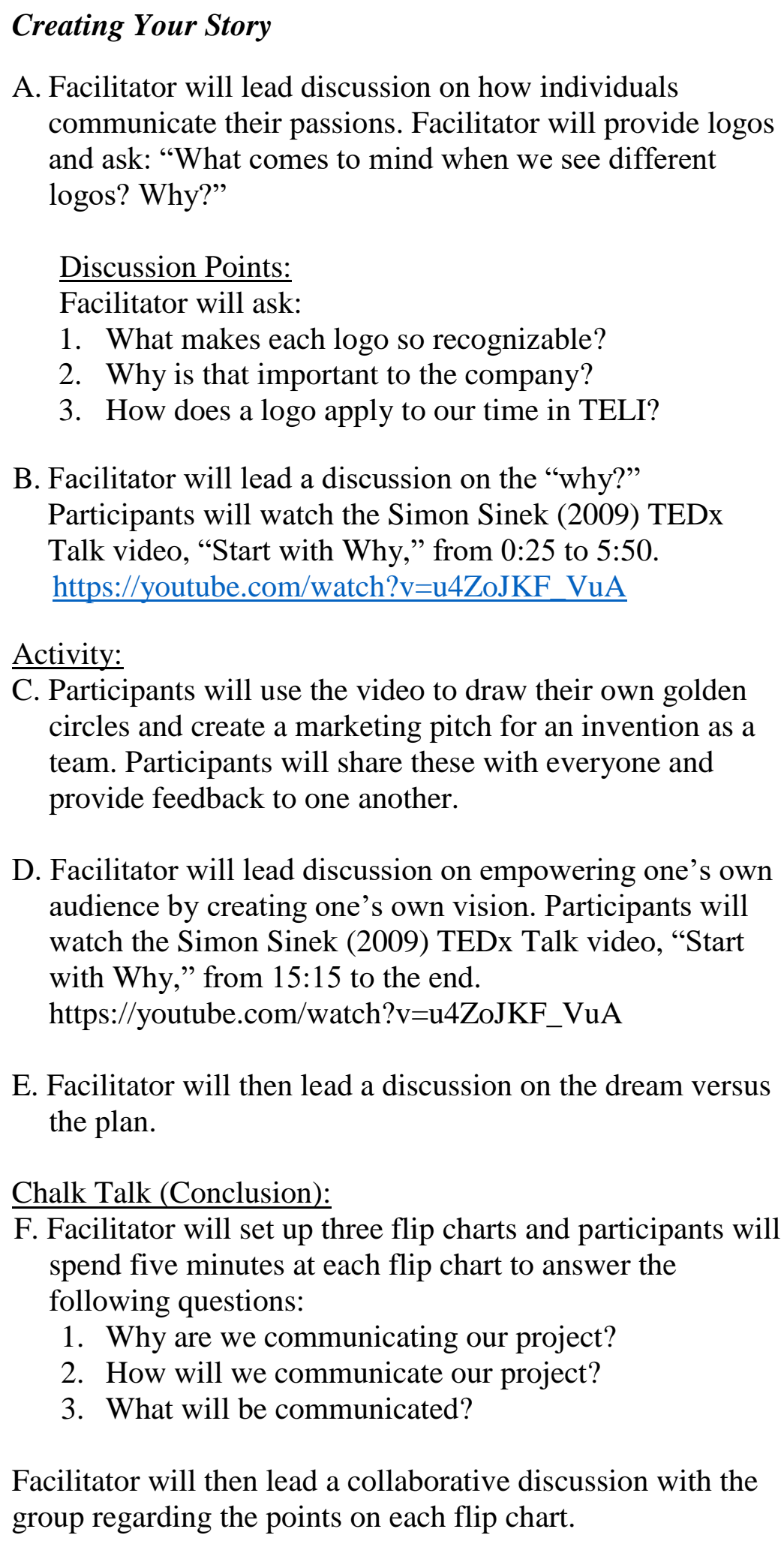 & 2 hours \\
\hline
\end{tabular}




\begin{tabular}{|c|c|c|}
\hline $\begin{array}{l}\text { Facilitator leads } \\
\text { discussion } \\
\text { following the } \\
\text { video }\end{array}$ & $\begin{array}{l}\text { Strengths Video } \\
\text { A. Facilitator will introduce the Marcus Buckingham (2015) } \\
\text { video, "The Truth About You," and ask participants to } \\
\text { think about their strengths and how to use them in future } \\
\text { leadership roles. https://youtube.com/watch?v=UCQ4e0i- } \\
\text { aFM } \\
\text { Discussion Points: } \\
\text { Facilitator will ask: } \\
\text { 1. How can you become one of the } 20 \text { percent of people } \\
\text { who uses their strengths every day? } \\
\text { 2. How can you work with others to promote your } \\
\text { strengths rather than focusing on fixing your } \\
\text { weaknesses? } \\
\text { 3. How do you communicate your strengths with others } \\
\text { who do not have a grasp on CliftonStrengths? } \\
\text { 4. Was there anything you disagree with or would find } \\
\text { difficult to accomplish that Marcus Buckingham } \\
\text { discussed in the video? } \\
\text { 5. What is everyone's top takeaway from the video? }\end{array}$ & 1 hour \\
\hline $\begin{array}{l}\text { Facilitator } \\
\text { provides } 20 \\
\text { minutes of } \\
\text { instruction, and } \\
\text { participants } \\
\text { complete } \\
\text { personalized } \\
\text { action plans }\end{array}$ & 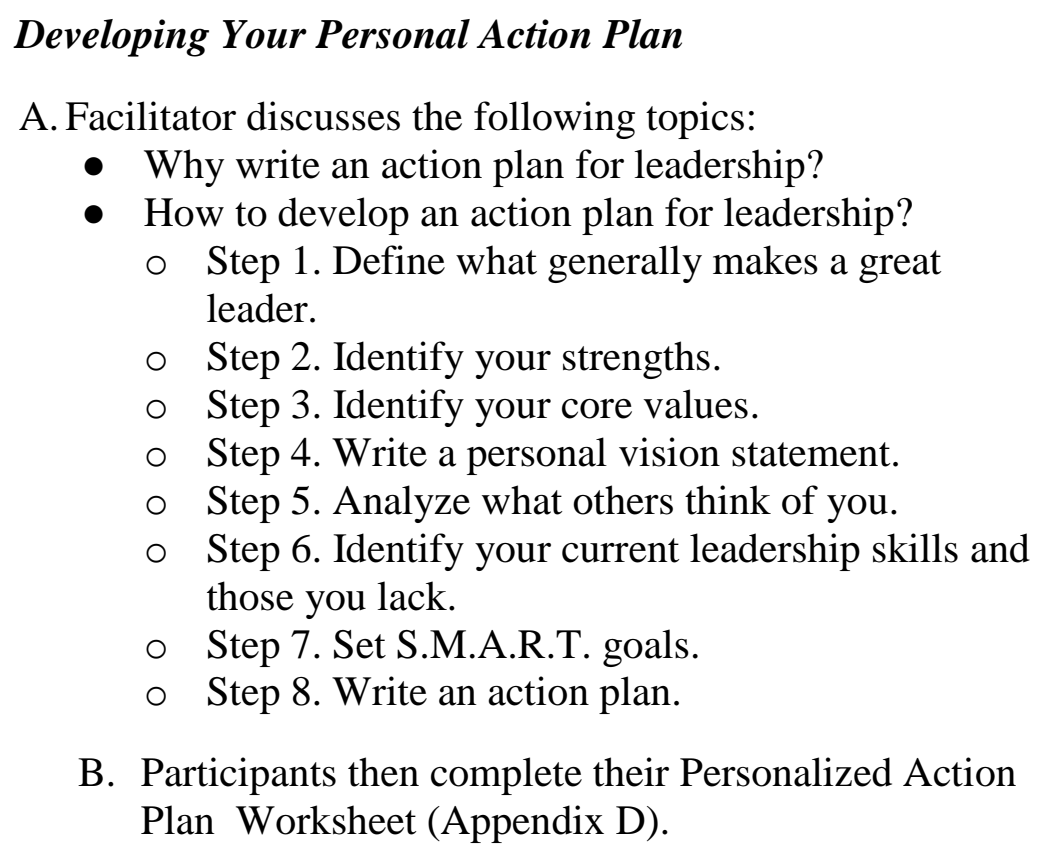 & 45 minutes \\
\hline
\end{tabular}




\section{Goal 2}

To network with other teens interested in learning about the issues facing youth and communities.

\section{Key Concepts:}

1. Get-acquainted activities will provide TELI participants with an opportunity to get to know one another.

2. Participants will learn different generational profiles, explore tools for effective generational collaboration, and understand how to use social media between generations.

3. Participants will engage in reflection with peers to develop a community of practice around leadership.

4. Participants will learn networking and proper etiquette for professional dinners and networking events.

5. Participants will be able to develop an effective marketing plan for the TELI program.

\begin{tabular}{|c|c|c|}
\hline Who? & What? & How long? \\
\hline $\begin{array}{l}\text { Facilitator leads } \\
\text { activities }\end{array}$ & $\begin{array}{l}\text { Get-Acquainted Activities } \\
\text { A. Facilitator leads get-acquainted activities and icebreakers. } \\
\text { Activities can be designed to fit the space, number of } \\
\text { participants, and type of activity desire. Here is a resource } \\
\text { for icebreakers (Ultimate Camp Resource } 2017 \text { a). } \\
\text { www.ultimatecampresource.com/site/camp-activities/ice- } \\
\text { breakers.html } \\
\text { B. Facilitator will provide an example of an introduction for a } \\
\text { leadership team member. The introduction should include } \\
\text { information on the individual's educational and } \\
\text { professional background, a compliment on their } \\
\text { achievements, and an interesting fact. Participants will then } \\
\text { be paired to learn more about another participant. Pairs } \\
\text { will then take turns standing up in front of the group and } \\
\text { providing an introduction for their partner. }\end{array}$ & $\begin{array}{l}\text { Two 45- } \\
\text { minute } \\
\text { sessions }\end{array}$ \\
\hline $\begin{array}{l}\text { Facilitator leads } \\
\text { discussion and } \\
\text { exercise }\end{array}$ & 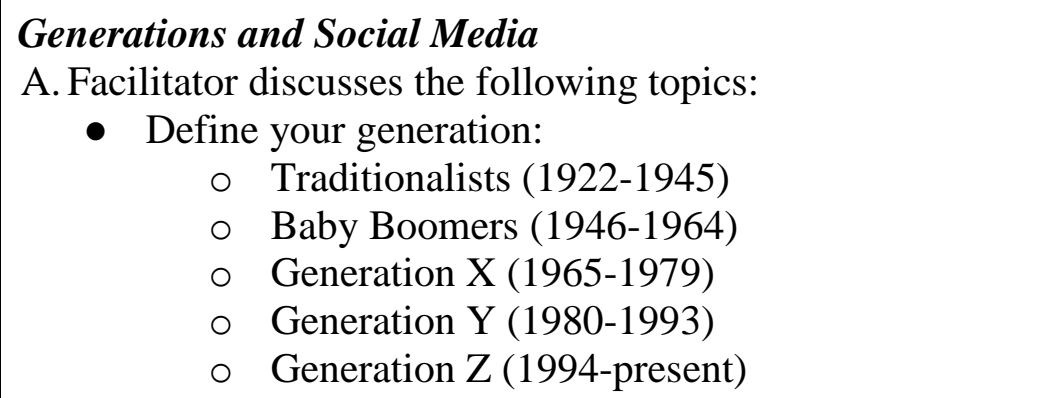 & $\begin{array}{l}2 \text { hours and } \\
30 \text { minutes }\end{array}$ \\
\hline
\end{tabular}




\begin{tabular}{|c|c|c|}
\hline & $\begin{array}{l}\text { - Comparison of generations. } \\
\text { - Talking 'bout my generation. } \\
\text { Discussion questions/topics: } \\
\text { 1. Would you describe your actual generation } \\
\text { differently? If so, how? } \\
\text { 2. Discuss whether or not you identify with the } \\
\text { characteristics of another generation. } \\
\text { - Breaking down generational differences. } \\
\text { Activity } \\
\text { B. Participants will get in small groups and identify teachers } \\
\text { that instruct them at school. Participants will be asked to } \\
\text { identify teachers who are baby boomers or traditionalists } \\
\text { and those who are Generation Y. Participants will then } \\
\text { compare and contrast their teaching techniques/strategies, } \\
\text { their preferred method of communication, and their } \\
\text { relationships with those teachers. Groups will report out. } \\
\text { - Generational collisions. } \\
\quad \text { O Examine the differences. } \\
\quad \text { A Appreciate the similarities. } \\
\text { - How can we all get along? } \\
\text { C. Facilitator will discuss social media. } \\
\text { - Different types of social media. } \\
\text { - Discuss generational differences in social media } \\
\text { usage/preferences. } \\
\text { - Why do certain generations prefer one type of social } \\
\text { media over another? }\end{array}$ & \\
\hline $\begin{array}{l}\text { Facilitator leads } \\
\text { discussion, and } \\
\text { participants are } \\
\text { given free time }\end{array}$ & $\begin{array}{l}\text { Reflection and Social Time } \\
\text { A. Facilitators will lead a discussion at the completion of } \\
\text { each day and virtual check-in. Reflection topics will vary } \\
\text { based on the day. }\end{array}$ & $\begin{array}{l}\text { Two 1-hour } \\
\text { sessions }\end{array}$ \\
\hline Participants & $\begin{array}{l}\text { Networking with the Guest Panel } \\
\text { A. Participants are given the opportunity to practice their } \\
\text { networking skills with the guest panel from their group } \\
\text { project presentation. The guest panel is composed of four } \\
\text { diverse individuals from the agricultural sector in } \\
\text { Virginia. }\end{array}$ & 30 minutes \\
\hline
\end{tabular}




\begin{tabular}{|c|c|c|}
\hline $\begin{array}{l}\text { Facilitator leads } \\
\text { etiquette dinner }\end{array}$ & $\begin{array}{l}\text { Etiquette Dinner } \\
\text { A. Facilitator uses a PowerPoint presentation while walking } \\
\text { participants through the etiquette for a formal dinner. } \\
\text { - Why is it important? } \\
\text { - Invitations. } \\
\text { - Rhat to wear. } \\
\text { - Beceptions and buffets. } \\
\text { - Place settings. } \\
\text { - Dining styles. } \\
\text { - Ordering food and beverages. } \\
\text { - Difficult food. } \\
\text { - Leaving the table. } \\
\text { - Follow up. }\end{array}$ & $\begin{array}{l}1 \text { hour and } \\
30 \text { minutes }\end{array}$ \\
\hline $\begin{array}{l}\text { Participants } \\
\text { create } \\
\text { marketing tools }\end{array}$ & $\begin{array}{l}\text { TELI Marketing Activity } \\
\text { A. Facilitator provides participants with the prompt of } \\
\text { creating marketing tools for the TELI program. } \\
\text { Participants are provided with iPads and photos from the } \\
\text { TELI cohort to create marketing videos about their time in } \\
\text { TELI that should be aimed at enticing future participants } \\
\text { to apply for the program. }\end{array}$ & 1 hour \\
\hline
\end{tabular}




\section{Goal 3}

To design a team project to address community leadership needs in Virginia.

\section{Key Concepts:}

1. Participants will build trusting relationships through effective communication and problem-solving with team members.

2. Participants will learn to use facilitation skills to develop a plan of work and carry out a group project to address community leadership needs.

3. Participants will develop skills for communicating with team members and holding others accountable.

\section{Additional Resources and Insights on Group Projects:}

- Collaboration Tools and Tips (Appendix E): It is recommended that Collaboration Tools and Tips be provided to participants for their long-distance collaborations with their teams, which are made up of individuals from across the state.

- Mentoring responsibilities: It is recommended for mentors and youth participants to set expectations for one another. Mentors and their teams should outline an appropriate timeline for check-ins, mode of communication, and platforms for sharing information.

\begin{tabular}{|c|c|c|}
\hline Who? & What? & How long? \\
\hline $\begin{array}{l}\text { Trained ropes } \\
\text { course } \\
\text { instructor leads } \\
\text { session }\end{array}$ & $\begin{array}{l}\text { Ropes Course - Team Building } \\
\text { A. Participants will engage in team-building activities on a } \\
\text { ropes course. This session will include role clarification, } \\
\text { trust building, problem-solving, and communication as } \\
\text { key topics. Group reflection should be led throughout this } \\
\text { activity. Here is a resource on team building (Ultimate } \\
\text { Camp Resource } 2017 \mathrm{~b} \text { ): } \\
\text { www.ultimatecampresource.com/site/camp- } \\
\text { activities/team-building-activities.html. }\end{array}$ & $\begin{array}{l}2 \text { hours and } \\
30 \text { minutes }\end{array}$ \\
\hline $\begin{array}{l}\text { Facilitator leads } \\
\text { discussion and } \\
\text { exercise }\end{array}$ & $\begin{array}{l}\text { Group Facilitation Training } \\
\text { A. Defining facilitation. } \\
\text { - Distribute Post-it notes to each group. Have each } \\
\text { member in the group write two or three words (one on } \\
\text { each Post-it) that describes what they believe } \\
\text { facilitation is. } \\
\text { - Have the members in the group combine all of the } \\
\text { words generated to create their own definition of } \\
\text { facilitation. } \\
\text { - Compare the group-generated definition of facilitation } \\
\text { with the actual definition. }\end{array}$ & 3 hours \\
\hline
\end{tabular}


B. Behaviors that hinder, behaviors that help.

- Using a flip chart, create two columns and list all behaviors that fall under each category.

o Behaviors that hinder (prevent, slow down, stop).

o Behaviors that help (support, generate, create).

- Using the list of behaviors that help, create a set of working agreements (these are rules or expectations that will help the group achieve success as they move forward with their teams).

C. Facilitation core competencies.

- Distribute the facilitation core competency cards to each group. Have them brainstorm a role-play that will demonstrate what NOT TO DO to achieve the core competency. After the first role-play is shown to the other groups, have them repeat the role-play, identifying what TO DO to achieve the core competency. Have the groups correctly identify the core competency.

D. Road map.

- Distribute the Facilitation Road Map cards to select participants. Have the group physically place the group members in the correct chronological order. Have them observe how they interact and the process they used to complete the sequence. Show them the correct sequence and discuss.

E. Group project brainstorming.

- Community-issue project teams are created, and team members work together to map out different issues and then identify an agreed-upon community issue to develop a response to. Participants then consider the contributing factors of the issues, audience, and different ways to address the issue.

F. Group project team working agreements. 


\begin{tabular}{|c|c|c|}
\hline & $\begin{array}{l}\text { Participants work with their group project team } \\
\text { members to create an agreed-upon working agreement. } \\
\text { It is essential this working agreement include how team } \\
\text { members will communicate and schedule meetings } \\
\text { based on their geographical dispersion throughout the } \\
\text { state. }\end{array}$ & \\
\hline $\begin{array}{l}\text { Participants } \\
\text { complete } \\
\text { worksheet with } \\
\text { guidance from } \\
\text { their mentors }\end{array}$ & $\begin{array}{l}\text { Developing Your Plan of Work } \\
\text { A. Participants use the Action Planning Worksheet } \\
\text { (Appendix F) to provide responses to the following } \\
\text { prompts: } \\
\text { - Identified need: Describe the issue you wish to address. } \\
\text { - Goal statement: Clearly define what you want to do to } \\
\text { address the issue. } \\
\text { - Program response: Describe the individual activities } \\
\text { needed to meet your goals. } \\
\text { - Program outcomes: Describe what you want to happen } \\
\text { because of your program/activities. }\end{array}$ & $\begin{array}{l}2 \text { hours and } \\
15 \text { minutes }\end{array}$ \\
\hline $\begin{array}{l}\text { Participants } \\
\text { with guidance } \\
\text { from mentors }\end{array}$ & $\begin{array}{l}\text { Group Project and Presentation } \\
\text { A. Participants work in teams of four to five along with } \\
\text { mentors to complete research, conduct interviews with } \\
\text { stakeholders, and create a response to an identified } \\
\text { community need. } \\
\text { B. Participants meet outside the designated TELI meeting } \\
\text { times to work with their team members to create their } \\
\text { final project. Mentors provide guidance during select } \\
\text { meetings. } \\
\text { C. Participants use the TELI Group Project PowerPoint } \\
\text { Outline (Appendix G) to present the progress on their } \\
\text { project at the second virtual check-in. At that time, } \\
\text { participants receive feedback from the TELI leadership } \\
\text { team and their peers. } \\
\text { D. At the final weekend, groups make a final presentation in } \\
\text { front of a panel of agricultural professionals. The panel, } \\
\text { TELI leadership team members, and TELI participants } \\
\text { provide feedback using the TELI Group Project Feedback } \\
\text { Form (Appendix H). }\end{array}$ & $\begin{array}{l}3 \text { hours of } \\
\text { in-person } \\
\text { work }\end{array}$ \\
\hline $\begin{array}{l}\text { Facilitator leads } \\
\text { discussion }\end{array}$ & Giving and Receiving Feedback & 45 minutes \\
\hline
\end{tabular}




\begin{tabular}{|c|c|c|}
\hline & $\begin{array}{l}\text { A. Facilitator leads a discussion on giving and receiving } \\
\text { constructive feedback, including the following topics: } \\
\text { - What is constructive feedback? } \\
\text { - Why is constructive feedback important? } \\
\text { - Riving constructive feedback. } \\
\text { Discussion questions/topics: } \\
\text { 1. Share a time with us when you received feedback. } \\
\text { Was it constructive? Why or why not? } \\
\text { 2. Share a time with us when you shared feedback. Was } \\
\text { it well-received? If so, what did you do well? If not, } \\
\text { what could have been improved? }\end{array}$ & \\
\hline $\begin{array}{l}\text { A team leader } \\
\text { facilitates } \\
\text { discussion and } \\
\text { exercises }\end{array}$ & $\begin{array}{l}\text { Crucial Conversations } \\
\text { A. Facilitator leads a session that includes the following } \\
\text { topics: } \\
\text { - Components of crucial conversations. } \\
\text { - CPR: content, pattern, relationships. } \\
\text { - Your style under stress. } \\
\text { - Personal reflection on a crucial conversation. } \\
\text { - Stories versus facts. } \\
\text { - Creating shared meaning for dialogue. }\end{array}$ & 2 hours \\
\hline
\end{tabular}




\section{Goal 4}

To learn more about the advocacy and outreach that will improve the lives of others.

\section{Key Concepts:}

1. Participants will learn about legislative advocacy and how they can function as advocates.

2. Participants will take part in a community service project.

\begin{tabular}{|c|c|c|}
\hline Who? & What? & How long? \\
\hline $\begin{array}{l}\text { Facilitator leads } \\
\text { discussion } \\
\text { (guest speaker } \\
\text { from } \\
\text { government } \\
\text { agency) }\end{array}$ & $\begin{array}{l}\text { Legislative Advocacy } \\
\text { A. Facilitator leads a session, which includes the following } \\
\text { topics: } \\
\text { - Makeup of state assembly. } \\
\text { - The executive branch. } \\
\text { - Why is advocacy important? } \\
\text { - Key "secrets" for success in lobbying. } \\
\text { - Getting started in advocacy and lobbying. } \\
\text { - Who's my legislator? } \\
\text { - Coalitions/partners. } \\
\text { - Current issues for agriculture in Virginia. }\end{array}$ & 30 minutes \\
\hline $\begin{array}{l}\text { Facilitator leads } \\
\text { the service } \\
\text { project }\end{array}$ & $\begin{array}{l}\text { Service Project } \\
\text { A. Participants take part in a community service project and } \\
\text { discussion the benefits of community service. Participants } \\
\text { discuss how to identify service that aligns with their } \\
\text { passion. Participants will discuss how service relates to } \\
\text { advocacy. }\end{array}$ & $\begin{array}{l}2 \text { hours and } \\
30 \text { minutes }\end{array}$ \\
\hline
\end{tabular}


To access the impacts of TELI in the areas of civic engagement, service, and personal development, Cohort 1 participant responses indicated statistically significant changes in each of the 16 common measures evaluated. We assigned 4-H's 16 common measures to evaluate the goals of the TELI program. The common measures were selected to represent: understanding of self (three measures), developing a network (three measures), community program-solving (six measures), and advocacy (four measures). In Year 2, respondents indicated statistically significant changes in each of the 14 common measures evaluated (table 1). In the first cohort, the measures "I have talents I can offer others" and "I know community leaders who support me" were also evaluated. Both variables indicated statistically significant change. However, these measures were not evaluated with Cohort 2 due to an error in developing the online survey.

Table 1. Means and significance of 4-H common measures before and after TELI participation.

\begin{tabular}{lccccccc}
\hline \multirow{1}{*}{ Construct } & \multicolumn{3}{c}{ Cohort $1(\mathbf{n}=\mathbf{1 2})$} & \multicolumn{3}{c}{ Cohort $2(\mathbf{n}=\mathbf{1 4})$} \\
\cline { 2 - 8 } & $\mathbf{Z}$ & $\boldsymbol{p}$ & Sig. & $\mathbf{Z}$ & $\boldsymbol{p}$ & Sig. \\
\hline Understanding of self & -3.077 & .002 & $*$ & -2.585 & .010 & $*$ \\
Developing a network & -2.952 & .003 & $*$ & -2.992 & .003 & $*$ \\
Community problem solving & -3.195 & .001 & $*$ & -3.192 & .001 & $*$ \\
Advocacy & -2.955 & .003 & $*$ & -3.240 & .001 & $*$
\end{tabular}

Note: $* \mathrm{p}<.05$. Constructs were evaluated using a four-point Likert scale $(4=$ very confident, $3=$ confident, 2 $=$ somewhat confident, and $1=$ not confident).

\section{Program Improvement from Participant Feedback}

Based on feedback from the cohorts, several changes were made to the TELI program. A second day was added to the final weekend, allowing more social time for team members to develop a stronger network and form better relationships with other cohort members. Additionally, project mentoring was altered to include a formal mentor who was assigned to each project team on the first weekend. Prior to formal mentorship, mentoring was provided from TELI leadership team members who would communicate with each team and provide feedback. The TELI leadership team assigned mentors to each team and wrote guidelines for serving as a mentor. A session on using the virtual session technology was also included for participants to be better prepared to interact in the virtual platform. 
4-H (4-H National Headquarters). 2011. “4-H Citizenship Program.” Washington, DC.

Buckingham, M. 2015. "The Truth About You" (video). EEC Education. www.youtube.com/watch?v=UCQ4e0i-aFM.

Chickering, A. 1993. "The Seven Vectors: An Overview." In Education and Identity, 4352. San Francisco: John Wiley \& Sons.

Grint, K. 2005. "Problems, Problems, Problems: The Social Construct of 'Leadership."” Human Relations 58 (11): 1467-94.

Lambur, M. 2019. "VCE Program Design and Implementation." Accessed March 31. www.intra.ext.vt.edu/support/process/design.html\#prog.

Shamir, B., and G. Eilam. 2005. “'What's Your Story?' A Life-Stories Approach to Authentic Leadership Development.” The Leadership Quarterly 16 (3): 395-417. doi:10.1016/j.leaqua.2005.03.005.

Sinek, S. 2009. "Start with Why: How Great Leaders Inspire Action." TEDx Talk. Sept. 15. Puget Sound, WA. www.youtube.com/watch?v=u4ZoJKF_VuA.

Villarruel, F. A., D. F. Perkins, L. M. Borden, and J. G. Keith, eds. 2003. Community Youth Development: Programs, Policies, and Practices. Thousand Oaks, CA: Sage Publications.

Ultimate Camp Resource. 2017a. "Icebreakers." www.ultimatecampresource.com/site/camp-activities/ice-breakers.html.

Ultimate Camp Resource. 2017b. "Team Building Activities." www.ultimatecampresource.com/site/camp-activities/team-building-activities.html.

VCE (Virginia Cooperative Extension). 2010. Virginia's Strategic Plan for Virginia Cooperative Extension: 2011-2016. Office of Communications and Marketing. College of Agriculture and Life Sciences, Virginia Tech. https://ext.vt.edu/content/dam/ext_vt_edu/strategic-planning/strategic-plan.pdf.

Wenger, E. 2011. Communities of Practice: A Brief Introduction. Scholars' Bank, University of Oregon Libraries. https://scholarsbank.uoregon.edu/xmlui/bitstream/handle/1794/11736/A\%20brief\% 20 intr oduction $\% 20$ to $\% 20 \mathrm{CoP}$.pdf? sequence $=1 \&$ isAllowed $=\mathrm{y}$. 
Appendix A. TELI Recruitment Flyer 33

Appendix B. Nomination Form $\quad 34$

Appendix C. Teen Application Form $\quad 36$

Appendix D. Personalized Action Plan Worksheet 39

Appendix E. Collaboration Tools and Tips 41

Appendix F. Action Planning Worksheet 42

Appendix G. TELI Group Project PowerPoint Outline 44

Appendix H. TELI Group Project Feedback Form 47 


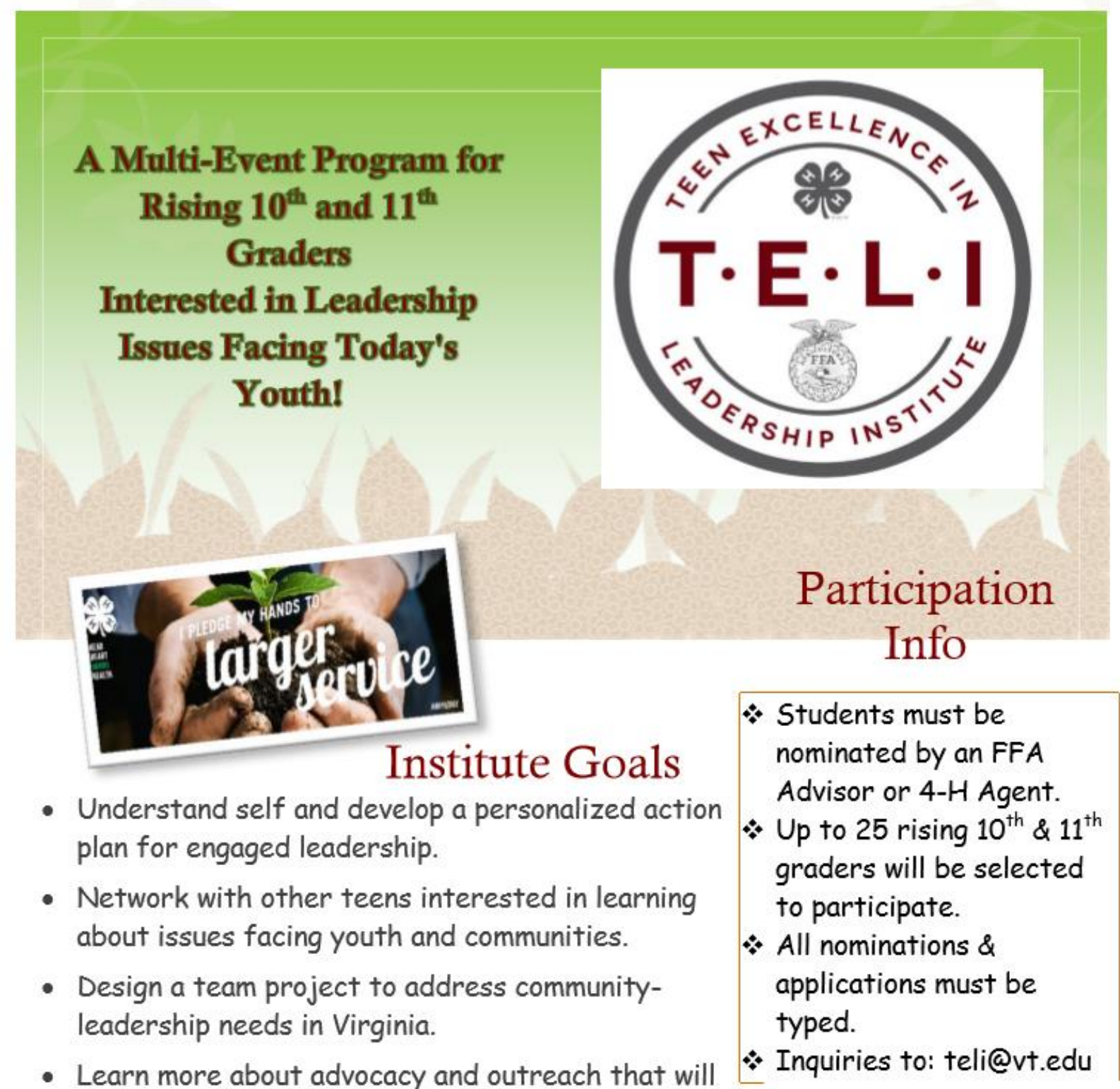
improve the lives of others.

\section{SAVE THE DATE!}

Nominations \& Applications

Due: Sept. 1, 2015

Notification Date:

Sept. 15,2015

\section{Institute Dates/Locations:}

Nov. 6-8, 2015 (W.E.Skelton 4-H Center)

January 12, 2016 (virtual meeting)

February 18, 2016 (virtual meeting)

April 8-10, 2016 (Airfield 4-H Center)

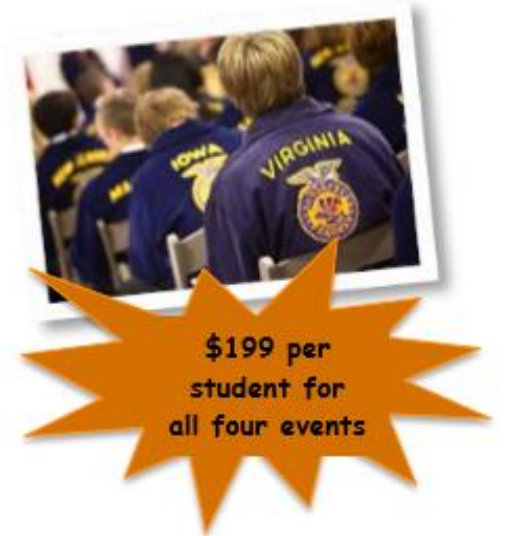




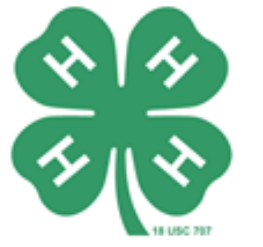

\section{Teen Excellence in Leadership Institute (TELI) Nomination Form}

The Teen Excellence in Leadership Institute (TELI) Planning Committee will select up to 25 qualified teens to participate in the program, November 6-8, 2015 at the W.E. Skelton 4-H Educational Center in Wirtz, VA, January 12, 2016 (online meeting), February 18, 2016 (online meeting) and April 8-10, 2016 at the Airfield 4-H Educational Center in Wakefield, VA. All nominations and applications are due on September 1, 2015 by 5:00 PM. You may email completed nomination forms to teli@vt.edu. Please note that this form needs to accompany the application form and that the application form MUST be typed to be accepted. The cost to participate in this program is $\$ 199$ and includes lodging, meals and materials.

Name of teen you are nominating:

Unit or Chapter:

\section{Address:}

City, State \& Zip:

Email Address:

Home Phone Number: Cell Phone Number:

Number of years as a 4-H or FFA Member:

Date of Birth:

As the nominator and 4-H Agent or FFA Advisor of the above mentioned teen, checking the box indicates my willingness to take an active role in this program by helping with transportation, | chaperoning and mentoring participants.

Leadership positions held?

What is it about this individual's leadership ability that stands out above others? 
How has this individual contributed to $4-\mathrm{H}$ and/or FFA in the areas of leadership, citizenship, community service and promotion?

What do you think will benefit this individual the most through participation in this Institute?

Other comments:

Printed Name of Nominator

Title

Phone Number
Signature of Nominator

Date

Email Address 


\section{Teen Excellence in Leadership Institute (TELI) Application Form}

The Teen Excellence in Leadership Institute (TELI) Planning Committee will select up to 25 qualified teens to participate in the program, November 6-8, 2015 at the W.E. Skelton 4-H Educational Center in Wirtz, VA, January 12, 2016 (online meeting), February 18, 2016 (online meeting) and April 8-10, 2016 at the Airfield 4-H Educational Center in Wakefield, VA. All applications are due on September 1, 2015 by 5:00 PM. You may email completed application forms to teli@vt.edu. Please note that the nomination form must accompany the application and that this application MUST be typed to be accepted. The cost to participate in this program is $\$ 199$ and includes lodging, meals and materials.

Name:

Unit or Chapter:

Address:

City, State \& Zip:

Email Address:

Home Phone Number: Cell Phone Number:

Number of years as a 4-H or FFA Member:

Date of Birth:

T-Shirt Size:

\section{PARTICIPANT MEDIA RELEASE}

The Virginia Polytechnic Institute and State University/College of Agriculture and Life Sciences (CALS) periodically uses electronic and traditional media (e.g., photographs, video, audio footage, testimonials) for publicity and educational purposes. By my signature on this form, I acknowledge receipt of this document and give permission to the College of Agriculture and Life Sciences and its designee to use such reproductions for educational and publicity purposes in perpetuity without further consideration from me.

I understand that I will need to notify Virginia Tech/College of Agriculture and Life Sciences if any changes to my situation occur that will impact this media release permission.

a Yes a No

Why do you wish to participate in the Teen Excellence in Leadership Institute (TELI)? 
Please share your most rewarding experience as a teen leader in any capacity (4-H, FFA, or any civic/community service organization) and why that experience was so rewarding?

How have your leadership experiences contributed to your personal development?

Describe your personal view of "leadership" and a summary of your leadership experience. (Please include all relevant local, district, state, or national level experience).

Describe your personal philosophy regarding teamwork.

Describe your personal view of "service" and your experience with community service, service learning, and/or community outreach. (Please include all relevant local, state, or national level experience.)

Please identify two to three issues facing your community and how you and/or your peers might be able to personally address these issues and make a positive impact. 
Other comments you would like to share with the selection committee.

\section{Parent/Guardian Consent Statement}

As parent/guardian of

I am aware of the commitment he/she will incur if chosen to participate in T.E.L.I. I will attempt to ensure that he/she fulfills this commitment and do hereby give my consent for her/him to participate if chosen.

Signature of Parent/Guardian

Date 


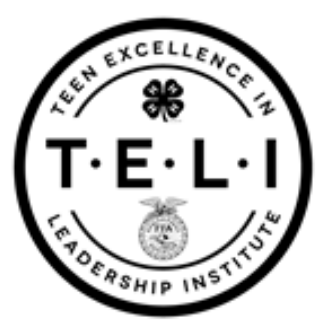

\section{Personalized Action Plan for Leadership}

This Action Plan worksheet will help you to determine your leadership goals and what you would like to achieve. List some goals you will set for yourself. These might include things you want to learn, to do, or to achieve as a leader. Your goals should be S.M.A.R.T (specific, measurable, attainable, relevant, and timely). You must be able to evaluate if you have achieved your goals.

Use this worksheet to help guide you in writing your personalized action plan for leadership.

What is your leadership vision?

Write your goals to help you achieve your vision:

To achieve your goals, you need a plan of action. This is a step-by-step list of what to do, what resources are needed, and who can help. Write your plan of action below.

1. Information to Gather (What do I need to find out?)

a.

b.

c. 
d.

e.

2. Resources needed (people, publications, material, equipment, etc.)

a.

b.

c.

d.

e.

\section{Steps to take to Achieve Goals}

a. Target Month:

b. Target Month:

c. Target Month:

d. Target Month:

e. Target Month:

f. Target Month:

g. Target Month:

4. Skills I Need to Learn or Improve Upon

a.

b.

c.

d.

e. 
APPENDIX E. COLLABORATION TOOLS AND TIPS

\section{Websites for Collaboration Tools and Tips}

- Get started with Hangouts - https://support.google.com/hangouts/answer/2944865?hl=en

- Start a Hangout - https://support.google.com/hangouts/answer/3115553?hl=en

- Get started with Google Drive -

https://support.google.com/drive/answer/2424384?hl=en\&ref topic=14940

- Top 15 Most Popular File Sharing Websites - http://www.ebizmba.com/articles/file-sharing-

websites 


\section{ACTION PLANNING WORKSHEET}

Name:_Group: 帅

Identified Need: Describe the issue you wish to address.

Goal Statement: Clearly define what you want to do to address the issue.

Program Response: Describe the individual activities needed to meet your goals.

\begin{tabular}{|l|l|l|l}
\hline Activity/Objective 1: & Who does what? Who & Supplies/Costs: & Completion Date:
\end{tabular}

\begin{tabular}{|c|c|c|c|}
\hline 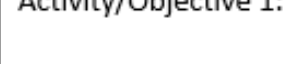 & is in charge? & & \\
\hline Activity/Objective 2: & $\begin{array}{l}\text { Who does what? Who } \\
\text { is in charge? }\end{array}$ & Supplies/Costs: & Completion Date: \\
\hline
\end{tabular}




\begin{tabular}{|l|l|l|l|}
\hline Program Response: Describe the individual activities needed to meet your goals. \\
\hline Activity/Objective 3: & $\begin{array}{l}\text { Who does what? Who } \\
\text { is in charge? }\end{array}$ & Supplies/Costs: & Completion Date: \\
& $\begin{array}{l}\text { Who does what? Who } \\
\text { is in charge? }\end{array}$ & Supplies/Costs: & Completion Date: \\
\hline Activity/Objective 4: & $\begin{array}{l}\text { Who does what? Who } \\
\text { is in charge? }\end{array}$ & Supplies/Costs: & Completion Date: \\
\hline Activity/Objective 4: & & & \\
& & & \\
\hline
\end{tabular}

Program Outcomes: Describe what you want to happen because of your program/activities.

Short-term:

Medium-term:

Long-term:

\begin{tabular}{|l|l|l|}
\hline \multicolumn{3}{|l|}{ Team Member Contact Information: } \\
\hline Name: & Email: & Phone: \\
\hline Name: & Email: & Phone: \\
\hline Name: & Email: & Phone: \\
\hline Name: & Email: & Phone: \\
\hline Name: & Email: & Phone: \\
\hline
\end{tabular}




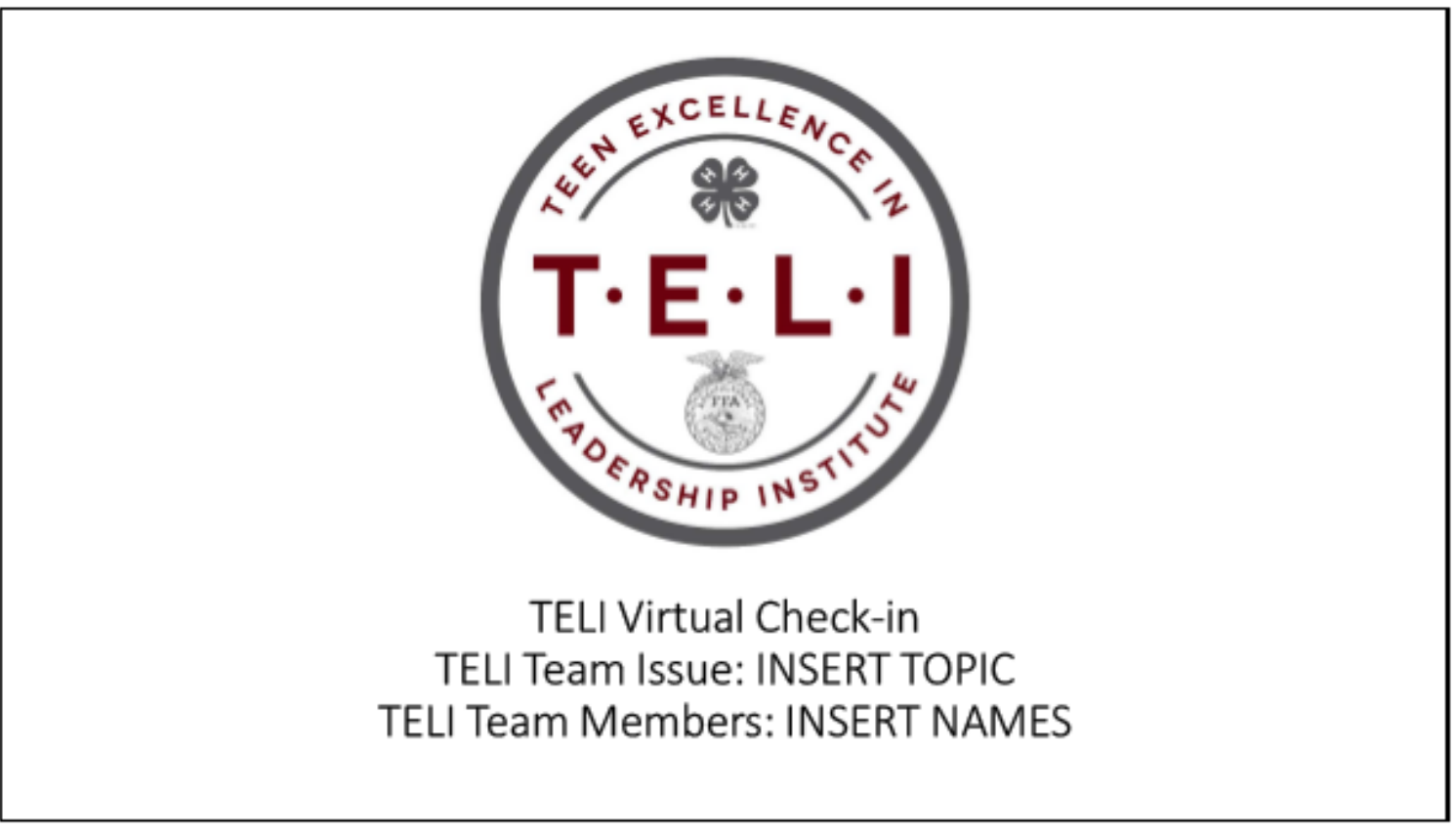

Identify Need:

(describe the issue you wish to address) 


\section{Goal Statement:}

(clearly define what you want to do to address the issue)

Program Response:

(describe individual activities needed to reach your program goals) 


\section{Program Outcomes:}

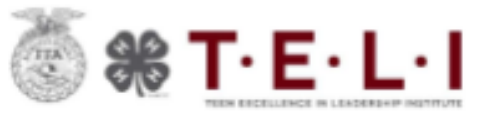

(describe what you want to happen as a result of your activities)

TELI Team Issue: INSERT TOPIC

TELI Team Members: INSERT NAMES

\section{Questions?}




\section{APPENDIX H. TELI GROUP PROJECT FEEDBACK FORM}
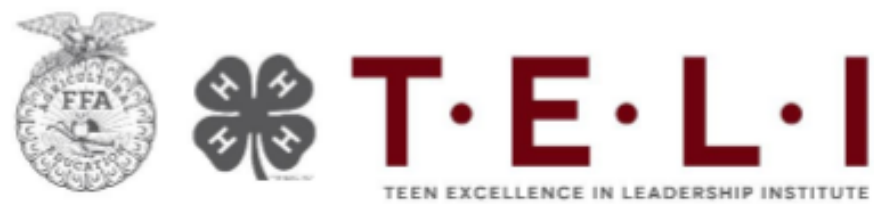

Each presentation should contain the following components: Identification of a community need; Goal Statement; Program Response; and Program Outcomes.

1. Does the group clearly define the community issue?

\begin{tabular}{|c|c|c|c|}
\hline Unclear; few details & $\begin{array}{c}\text { Somewhat clear; details } \\
\text { missing } \\
2 \text { points }\end{array}$ & Clear; detailed & $\begin{array}{c}\text { Very clear; very } \\
\text { detailed }\end{array}$ \\
& 3 points & 4 points \\
\hline
\end{tabular}

Comments:

2. Does the group clearly define what they will do to address the issue?

\begin{tabular}{|c|c|c|c|}
\hline Unclear; few details & $\begin{array}{c}\text { Somewhat clear; details } \\
\text { missing } \\
2 \text { points }\end{array}$ & Clear; detailed & $\begin{array}{c}\text { Very clear; very } \\
\text { detailed }\end{array}$ \\
\hline point & 3 points & 4 points \\
\hline
\end{tabular}

Comments:

3. Does the group describe individual activities needed to reach the group's program goals? How realistic are the group's project goals?

\begin{tabular}{|c|c|c|c|}
\hline Unclear; few details & $\begin{array}{c}\text { Somewhat clear; details } \\
\text { missing } \\
2 \text { points }\end{array}$ & Clear; detailed & $\begin{array}{c}\text { Very clear; very } \\
\text { detailed }\end{array}$ \\
1 point & 3 points & 4 points \\
\hline
\end{tabular}

Comments: 


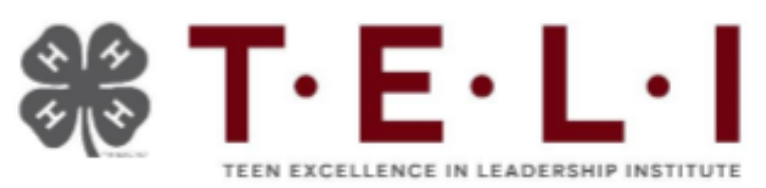

4. Does the group clearly define what they want to happen as a result of the planned activities?

\begin{tabular}{|c|c|c|c|}
\hline Poor & Fair & Good & Excellent \\
1 point & 2 points & 3 points & 4 points \\
\hline
\end{tabular}

Comments:

5. Rate the overall presentation delivery - appearance, voice, poise, grammar, effective/appropriate use of PowerPoint or other technological applications.

\begin{tabular}{|c|c|c|c|}
\hline Poor & Fair & Good & Excellent \\
1 point & 2 points & 3 points & 4 points \\
\hline
\end{tabular}

Comments:

Overall Feedback:

Total Score:

TELI Team Name:

Panelist Name: 